\title{
Sistem Pendukung Keputusan Pemilihan Asisten Dosen Menggunakan Metode SAW
}

\author{
Triana Elizabeth ${ }^{1}$, Tinaliah ${ }^{2}$ \\ ${ }^{1}$ Prodi Sistem Informasi STMIK GI MDP, Palembang \\ ${ }^{2}$ Prodi Manajemen Informatika AMIK MDP, Palembang \\ e-mail: ${ }^{1}$ trianaelizabeth@mdp.ac.id, ${ }^{2}$ tinaliah@mdp.ac.id
}

\begin{abstract}
Abstrak
Proses pemilihan asisten dosen diawali dengan memberikan pengumuman di web kampus. Persyaratannya adalah mendapatkan nilai A dan minimal sudah semester 3. Dikarenakan pemilihan asisten dosen mata kuliah hanya didasarkan pada nilai mata kuliah mahasiswa tersebut, ada beberapa dosen dan mahasiswa/i dikelas yang merasa asisten dosen pada mata kuliahnya tidak memberikan dampak positif dalam perkuliahan. Hal ini dikarenakan mahasiswa/i yang menjadi asisten dosen tidak aktif, sulit berkomunikasi dengan adik kelas, dan ada beberapa materi yang merekapun belum menguasai sehingga sulit untuk menjelaskannya ke adik tingkat. Oleh sebab itu, dibutuhkan suatu sistem pendukung keputusan yang dapat membantu bagian akademik mengambil keputusan siapa mahasiswa/i yang akan mereka pilih sebagai asisten dosen dan membantu kepala program studi teknik informatika untuk mendapatkan informasi tentang mahasiswa/i yang pernah menjadi asisten dosen. Sistem pendukung keputusan ini menerapkan logika Fuzzy Multiple Attribute Decission Making (FMADM) dan metode Simple Additive Weighting (SAW). Pembuatan sistem pendukung keputusan ini menggunakan aplikasi Netbeans IDE 8.2 dan MySQL sebagai databasenya.
\end{abstract}

Kata kunci-Fuzzy Multiple Decision Making (FMADM), Simple Additive Weighting (SAW), Netbeans IDE 8.2, MySQL

\begin{abstract}
The process of selecting the teaching assistant starts with announcements on the campus web. The requirement is to have an $\mathrm{A}$ and at least on $3^{\text {rd }}$ semester. Because the selection of lecturer assistant lecturers is only based on the value of the student's courses, there are a number of lecturers and students in the class who feel the teaching assistant in the course does not have a positive impact on lectures. This is because the students who are teaching assistants are not active, it is difficult to communicate with juniors, and there is some material that they have not mastered so it is difficult to explain it to juniors. Therefore, we need a decision support system that can help academics make decisions about who students they will choose as teaching assistants and help the head of the informatics engineering study program to get information about students who have been teaching assistants.This decision support system applying Decission Fuzzy Multiple Attribute Making (FMADM) and Simple Additive weighting method (SAW). This decision support system design uses the Netbeans IDE 8.2 application and MySQL as the database.
\end{abstract}

Keywords-Fuzzy Multiple Decision Making (FMADM), Simple Additive Weighting (SAW), Netbeans IDE 8.2, MySQL 


\section{PENDAHULUAN}

$\mathrm{B}$ erdasarkan kurikulum program studi Teknik Informatika, dapat diketahui bahwa untuk menyelesaikan kuliah program studi Teknik Informatika selama 8 semester, mahasiswa diwajibkan untuk mengambil 18 mata kuliah praktek wajib dengan total sks sebanyak 46 sks dan 7 mata kuliah praktek pilihan dengan total sks sebanyak 14 sks. 1 sks praktek terdiri dari 100 menit pertemuan tatap muka di lab komputer. Berdasarkan hasil kuesioner kepuasan mahasiswa, kebanyakan mahasiswa mengeluhkan pertemuan tatap muka praktek yang materinya cukup banyak dan sulit untuk diikuti. Hal ini disebabkan karena jumlah mahasiswa dalam mata kuliah praktek berkisar antara 25 - 35 mahasiswa sehingga ketika mahasiswa ingin bertanya tentang program yang dibuat, dosen pengampu mata kuliah tersebut sedang sibuk menangani program mahasiswa yang lain. Menangani masalah ini, maka program studi Teknik Informatika membuka lowongan bagi mahasiswa/i pada semester atas untuk menjadi asisten dosen mata kuliah praktek.

Proses pemilihan asisten dosen diawali dengan memberikan pengumuman di web kampus agar mahasiswa/i yang berminat menjadi asisten dosen, dapat mendaftarkan diri di bagian akademik. Persyaratannya adalah harus sudah lulus mata kuliah yang diampu dengan nilai A dan minimal sudah semester 3. Setelah mendaftar, mereka akan langsung menjadi asisten dosen untuk kelas yang telah dipilih oleh bagian akademik. Banyak mahasiswa/i yang mendaftar menjadi asisten dosen bahkan ada beberapa mata kuliah seperti mata kuliah dasar pemrograman dan basis data terapan yang banyak sekali mahasiswa/i mendaftar. Jika terlalu banyak, biasanya bagian akademik akan memilih berdasarkan siapa yang duluan mendaftar. Dikarenakan pemilihan asisten dosen mata kuliah hanya didasarkan pada nilai mata kuliah mahasiswa tersebut, ada beberapa dosen dan mahasiswa/i dikelas yang merasa asisten dosen pada mata kuliahnya tidak memberikan dampak positif dalam perkuliahan. Hal ini dikarenakan mahasiswa/i yang menjadi asisten dosen tidak aktif, sulit berkomunikasi dengan adik kelas, dan ada beberapa materi yang merekapun belum menguasai sehingga sulit untuk menjelaskannya ke adik tingkat.

Berdasarkan permasalahan yang dikemukakan sebelumnya, maka dibutuhkan suatu sistem pendukung keputusan yang dapat membantu bagian akademik mengambil keputusan siapa mahasiswa/i yang akan mereka pilih sebagai asisten dosen dan membantu kepala program studi teknik informatika untuk mendapatkan informasi tentang mahasiswa/i yang pernah menjadi asisten dosen.Sistem pendukung keputusan ini menerapkan logika Fuzzy Multiple Attribute Decission Making (FMADM) dan metode Simple Additive Weighting (SAW). Pembuatan sistem pendukung keputusan ini menggunakan bahasa pemrograman JAVA dengan aplikasi Netbeans IDE 8.2 dan MySQL sebagai databasenya.

\subsection{Fuzzy Multiple Attribute Decission Making (FMADM)}

[1] Fuzzy multiple Attribute Decision Making (FMADM) adalah suatu metode yang digunakan untuk mencari alternatif dengan kriteria tertentu. Inti dari FMADM adalah menentukan nilai bobot untuk setiap atribut, kemudian dilanjutkan dengan proses perankingan yang sudah diberikan. Pada dasarnya ada 3 pendekatan untuk mencari bobot atribut, yaitu: pendekatan subyektif, obyektif dan pendekatan integrasi antara subyektif dan objektif. Pendekatan subyektif, nilai bobot ditentukan berdasarkan subyektifitas dari para pengambil keputusan, sehingga beberapa faktor dalam proses perankingan alternatif bisa ditentukan secara bebas. Sedangkan pada pendekatan obyektif, nilai bobot dihitung secara matematis sehingga mengabaikan subyektifitas dari pengambil keputusan. 


\subsection{SAW (Simple Additive Weighting)}

[2] Konsep dasar metode SAW adalah mencari penjumlahan terbobot dari rating kinerja pada setiap alternatif pada semua aribut. Metode SAW membutuhkan proses normalisasi matriks keputusan $(\mathrm{X})$ ke suatu skala yang didapat diperbandingkan dengan semua rating alternatif yang ada. Formula untuk melakukan normalisasi sebagai berikut:

$$
r_{i j}=\left\{\begin{array}{c}
\frac{X_{i j}}{M i n X_{i j}}, j i k a j \text { adalah atribute keuntungan (benefit) } \\
\frac{M a x X_{i j}}{X_{i j}}, \text { Jika } j \text { adalah atribute biaya (cost) }
\end{array}\right.
$$

Keterangan:

Max $X_{i j}=$ Nilai terbesar dari setiap kriteria $\mathrm{i}$

Min $X_{i j}=$ Nilai terkecil dari setiap kriteria $i$

$\mathrm{X}_{\mathrm{ij}} \quad=$ Nilai atribut yang dimiliki dari setiap kriteria

Benefit $=$ jika nilai terbesar adalah terbaik

Cost $\quad=$ jika nilai terkecil adalah terbaik

Sedangkan nilai preferensi untuk setiap alternative (Vi) dapat dihitung dengan rumus sebagai berikut:

$$
\begin{aligned}
v_{i} & =\sum_{j=1}^{n} w_{j} r_{i j} \\
\text { Keterangan: } & \\
\mathrm{v}_{\mathrm{i}} & =\text { Ranking untuk setiap alternatif } \\
\mathrm{w}_{\mathrm{j}} & =\text { Nilai bobot ranking (dari setiap kriteria) } \\
\mathrm{r}_{\mathrm{ij}} & =\text { Nilai rating kinerja ternormalisasi }
\end{aligned}
$$

Nilai $V_{i}$ yang lebih besar mengindikasikan bahwa Alternatif $A_{i}$ lebih terpilih. Keunggulan dari metode SAW terletak pada kemampuannya dalam melakukan penilaian secara lebih tepat karena didasarkan pada nilai kriteria dan bobot tingkat kepentingan yang dibutuhkan. Selain itu, metode SAW dapat menyeleksi alternatif terbaik dari sejumlah alternatif yang ada kemudian dilakukannya proses perankingan yang jumlah nilai bobot dari semua kriteri dijumlahkan setelah menentukan nilai bobot dari setiap kriteria.

\subsection{Penelitian Terdahulu}

[3] Penelitian yang dilakukan sebelumnya oleh Triana Elizabeth dan Tinaliah adalah membuat sistem pendukung keputusan pemilihan peminatan program studi teknik informatika menggunakan SAW. Penulis merujuk penelitian ini dikarenakan logika yang digunakan sama dengan penelitian yang penulis yaitu FMADM. Selain itu, penelitian ini juga menggunakan metode SAW yaitu metode yang sama dengan yang penulis lakukan. Hasil impementasi dari penelitian ini baik dan memenuhi kebutuhan. Oleh sebab itu, penulis menggunakan logika FMADM dan metode SAW untuk pemilihan asisten dosen.

[4] Penelitian yang dilakukan oleh Bartolomius Harpad dan Shinta Palupi adalah membuat Sistem pendukung keputusan penerimaan asisten laboratorium komputer menggunakan metode SAW (studi kasus pada laboratorium komputer STMIK Widya Cipta Dharma Samarinda). Permasalahan yang melatari penelitian ini adalah belum adanya pemanfaatan teknologi informasi dalam proses pemilihan asisten. Teknologi informasi hanya digunakan untuk memberikan pengumuman seputar penerimaan asisten. Kriteria yang digunakan dalam penelitian ini adalah usia, kemampuan mengajar, tes wawancara, tes pemrograman, disiplin. Penelitian ini dilakukan dengan mencari bobot nilai untuk masing- 
masing atribut, kemudian dilakukan proses peringkat yang akan menentukan alternatif yang optimal.

[5] Penelitian yang dilakukan oleh Rosmiati berjudul Sistem Pendukung Keputusan Pemilihan Asisten Laboratorium Menggunakan Metode Simple Additive Weighting (SAW).

Penelitian ini dilakukan dikarenakan penerimaan asisten laboratorium STMIK Palangkaraya saat ini proses penilaiannya masih dilakukan dengan cara manual dan masih ditemukan ketidakefisienan serta kurang efektif dalam melakukan perhitungannya. Selain itu, peranan teknologi informasi terkadang hanya digunakan untuk memberikan pengumuman seputar penerimaan asisten dan belum digunakan pada proses pemilihan asisten tersebut. Sistem Pendukung Keputusan Pemilihan Asisten Laboratorium Pada STMIK Palangkaraya ini menerapkan metode Simple Additive Weighting (SAW) dan menggunakan bahasa pemograman Microsoft Visual Basic 6.0 dalam pengambilan keputusan dan sistem ini dapat digunakan dengan dibuktikannya validitas sistem pendukung keputusan mencapai $100 \%$.

[6] Penelitian ini berjudul Sistem Pendukung Keputusan Seleksi Penerimaan Calon Asisten Praktikum. SPK yang dibuat menggunakan metode SAW. Metode SAW dipilih berdasarkan hasil perangkingan menggunakan beberapa metode antara lain: SAW, WPM, TOPSIS, MODIFIED TOPSIS, GRA, PROMETHEE dan VIKOR. Dari hasil tersebut, didapatkan kesimpulan bahwa hasil perankingan menggunakan SAW lebih logis. Objek penelitian yang digunakan adalah data sampel pada daftar mahasiswa pada forum asisten STMIK AMIKOM Yogyakarta. Variabel yang digunakan adalah nilai mata kuliah, nilai tes akademis, nilai tes wawancara, nilai tes microteaching, presentasi, penguasaan materi, kelancaran menjawab pertanyaan, rekomendasi.

[7] Penelitian ini berjudul Penentuan Minat Asisten Dosen dengan Metode SAW Berbasis Web (Studi Kasus: STMIK STIKOM BALI). Kriteria calon asisten dosen adalah telah mengikuti mata kuliah yang bersangkutan, nilai mata kuliah minimal $\mathrm{B}$, dan lulus tes seleksi. Proses penerimaan asisten dosen di STMIK STIKOM Bali masih dilakukan manual sehingga mengakibatkan permasalahan berupa efisiensi waktu dan biaya operasional yang sangat tidak efisien dalam prosesnya. Metode yang digunakan adalah SAW (Simple Additive Weighting) yang mencari penjumlahan terbobot dari rating kinerja pada setiap alternatif dari semua atribut. Hasil dari sistem ini adalah suatu sistem berbasis web yang dapat membuat proses seleksi tes asisten dosen menjadi lebih efisien. Dalam sistem ini pelamar dapat memilih dua minat sekaligus yang nantinya dapat menentukan potensi akademis yang sebenarnya mereka kuasai.

[8] Penelitian yang dilakukan oleh Tati Mardiana berjudul sistem pendukung keputusan penerimaan asisten laboratorium komputer menggunakan metode AHP-TOPSIS. Penelitian ini dilakukan dikarenakan kesalahan dalam pengambilan keputusan menimbulkan ketidakpercayaan terhadap kualitas asisten laboratorium komputer yang diterima dan berdampak menurunnya pemahaman dan keterampilan mahasiswa terhadap mata kuliah tertentu. Enam kriteria yang dipakai adalah IPK, prestasi akademik, sikap, tanggung jawab, kepemimpinan, dan kerja sama. Dalam prosesnya, menggunakan logika Fuzzy Multiple Attribute Decision Making (FMADM) dengan metode Analytical Hierarchy Process (AHP) dan Technique for Order Preference by Similarity to Ideal Solution (TOPSIS). Hasil dari penelitian ini adalah membuat rangking alternatif asisten laboratorium untuk mendapatkan solusi terbaik. Berdasarkan pengujian terhadap sistem yang dibuat, sistem memiliki akurasi $100 \%$ sehingga dapat membantu kepala laboratorium komputer dalam memilih asisten laboratorium komputer yang akan membantu proses pembelajaran di laboratorium komputer secara objektif dan transparan.

[9] Penelitian ini berjudul Perancangan Sistem Pendukung Keputusan Seleksi Asisten Dosen Menggunakan Kombinasi Metode Profile Matching dan TOPSIS Berbasis Web Service. Penelitian ini dilakukan karena proses seleksi asisten dosen di fakultas Teknologi Informasi Universitas Kristen Satya Wacana (FTI UKSW) memakan waktu yang lama sehingga menyebabkan kegiatan praktikum menjadi terlambat untuk dimulai. Penelitian ini menggunakan

Triana, et.al (Sistem Pendukung Keputusan Pemilihan Asisten Dosen Menggunakan Metode SAW 
metode TOPSIS dan profile matching berbasis teknologi web service. Kriteria yang digunakan dalam penelitian ini adalah IPK, nilai mata kuliah yang didaftarkan, nilai tes seleksi, jumlah pengalaman asisten dosen sebelumnya, dan jumlah mata kuliah yang didaftarkan untuk menjadi asisten dosen. Hasil penelitian ini adalah ranking yang dapat digunakan untuk membantu dosen koordinator mata kuliah dalam menentukan calon asisten dosen yang akan diterima.

\section{METODE PENELITIAN}

Metode yang digunakan dalam rancang bangun sistem pendukung keputusan pemilihan mata kuliah peminatan adalah menggunakan metode iterative. [10] Metode iterative adalah metode dimana setiap tahapan atau fase pengembangan sistem dilaksanakan dengan memakai teknik pengulangan, dimana suatu proses dapat dilaksanakan secara berulang-ulang sampai mendapatkan hasil yang maksimal. [10] Adapun beberapa tahapan di dalam metode iterative adalah sebagai berikut:

1. Tahap Perencanaan Sistem

Pada tahap ini, dilakukan pendefinisian dari permasalahan yang ada untuk menentukan ruang lingkup, menentukan metodologi pengembangan aplikasi yang digunakan.

2. Tahap Analisis Sistem

Pada tahap ini, dilakukan analisis pada sistem yang telah ada dengan mengidentifikasipermasalahan, penentuan tujuan dari perbaikan sebuah sistem, dan mengidentifikasi kebutuhan pengguna.

3. Tahap Perancangan Sistem

Tahap ini menyatakan bagaimana membuat rancangan sistem dengan menggambarkan sebuah model sistem untuk menyelesaikan permasalahan.

4. Tahap Pembuatan Sistem

Pada tahap ini, dilakukan pembuatan sistem baru (hardware dan software) dengan alat bantu yang digunakan antara lain Netbeans IDE 8.2 sebagai aplikasi pengembang dan My SQL sebagai Sistem Manajemen Basis Data, serta bahasa pemrograman yang digunakan adalah bahasa java.

5. Tahap Implementasi Sistem

Pada tahap ini, dilakukan penginstalan database dan aplikasi desktop, serta pelatihan bagi pengguna aplikasi dan konversi ke sistem yang baru.

6. Tahap Pemeliharaan Sistem

Tahapan pemeliharaan sistem mencakup seluruh proses yang diperlukan untuk menjamin kelangsungan, kelancaran, dan penyempurnaan sistem yang telah dioperasikan.

\section{HASIL DAN PEMBAHASAN}

\section{Menentukan Alternatif}

Alternatif yang digunakan berjumlah 3 yaitu 2 mahasiswa yang sebelumnya pernah menjadi asisten dosen untuk mata kuliah dasar pemrograman (A1 dan A2) dan 1 mahasiswa yang belum pernah menjadi asisten dosen sebelumnya (A3).

2. Menentukan rating kecocokan

Rating kecocokan akan diberikan dengan ketentuan sebagai berikut: nilai 1 untuk kurang berpengaruh, nilai 2 untuk cukup berpengaruh dan nilai 3 untuk sangat berpengaruh.

3. Implementasi SAW (Simple Additive Weighting) 
Tahap awal implementasi SAW (Simple Additive Weighting) adalah dengan menentukan kriteria yang dibutuhkan. Kriteria yang dibutuhkan adalah IPK, tes pemrograman, kemampuan mengajar, nilai referensi, dan kerja sama. Maka, terdapat 5 kriteria untuk pengambilan keputusan yang dapat dilihat pada Tabel 1.

Tabel 1. Kriteria Pengambil Keputusan

\begin{tabular}{|c|l|}
\hline Kriteria & Keterangan \\
\hline C1 & IPK \\
\hline C2 & Tes pemrograman \\
\hline C3 & Kemampuan mengajar \\
\hline C4 & Nilai referensi \\
\hline C5 & Kerja sama \\
\hline
\end{tabular}

Tahap selanjutnya adalah menentukan bobot berdasarkan setiap kriteria. Bobot untuk IPK dapat dilihat pada Tabel 2.

Tabel 2. Bobot IPK

\begin{tabular}{|c|c|l|}
\hline IPK & Bobot & Keterangan \\
\hline $3,81-4,00$ & 5 & Sangat Baik \\
\hline $3,51-3,80$ & 4 & Baik \\
\hline $3,31-3,50$ & 3 & Cukup \\
\hline $3,00-3,30$ & 2 & Kurang \\
\hline$<3,00$ & 1 & Sangat Kurang \\
\hline
\end{tabular}

Nilai tes pemrograman, kemampuan mengajar, referensi, dan kerja sama dinilai minimum 0 dan nilai maksimumnya 100 . Nilai tes pemrograman didapat dari hasil tes bahasa pemrograman untuk mata kuliah yang dipilih. Nilai kemampuan mengajar dan kerja sama diberikan oleh dosen pembimbing akademik untuk mahasiswa yang mendaftar. Nilai referensi diberikan kepada mahasiswa/i yang sebelumnya pernah menjadi asisten dosen dan diberikan nilai oleh dosen tersebut. Sehingga, jika mahasiswa/i yang mendaftar belum pernah menjadi asisten dosen sebelumnya maka nilai referensinya adalah 1 . Bobot untuk nilai tes pemrograman, kemampuan mengajar, referernsi, dan kerja sama dapat dilihat pada Tabel 3.

Tabel 3. Bobot Tes Pemrograman, Kemampuan Mengajar, Nilai Referensi, Kerjasama

\begin{tabular}{|c|c|l|}
\hline Nilai & Bobot & Keterangan \\
\hline $86-100$ & 5 & Sangat Baik \\
\hline $76-85$ & 4 & Baik \\
\hline $66-75$ & 3 & Cukup \\
\hline $51-65$ & 2 & Kurang \\
\hline$<50$ & 1 & Sangat Kurang \\
\hline
\end{tabular}

Tahap selanjutnya adalah menentukan rating kecocokan setiap alternatif pada setiap kriteria berdasarkan bobot nilai. Rating kecocokan setiap alternatif dapat dilihat pada Tabel 4.

Tabel 4. Rating Kecocokan Setiap Alternatif

\begin{tabular}{|c|c|c|c|c|c|}
\hline Alternatif & \multicolumn{5}{|c|}{ Kriteria } \\
\hline & C1 & C2 & C3 & C4 & C5 \\
\hline A1 & 5 & 3 & 4 & 3 & 2 \\
\hline A2 & 4 & 4 & 4 & 2 & 3 \\
\hline
\end{tabular}




\begin{tabular}{|l|l|l|l|l|l|}
$\mathrm{A} 3$ & 5 & 3 & 3 & 1 & 4 \\
\hline
\end{tabular}

Tahap berikutnya adalah menentukan nilai vektor bobot berdasarkan tingkat kepentingan masing masing kriteria. Nilai vektor bobot dapat dilihat pada Tabel 4.

Tabel 5. Nilai Vektor Bobot

\begin{tabular}{|l|c|c|c|c|c|}
\hline Kriteria & C1 & C2 & C3 & C4 & C5 \\
\hline Bobot & 3 & 2 & 2 & 2 & 3 \\
\hline
\end{tabular}

Tahap selanjutnya adalah membuat matriks keputusan berdasarkan kriteria. Hal ini dilakukan dengan melakukan normalisasi matriks proses normalisasi matriks keputusan (X) ke suatu skala yang didapat diperbandingkan dengan semua rating alternatif yang ada dan jika nilai terbesar adalah nilai terbaik (benefit). Hasil perhitungan nilai $\mathrm{X}$ dan nilai normalisasi $\mathrm{R}$ dapat dilihat sebagai berikut:

$X=$\begin{tabular}{|l|l|l|l|l|}
\hline 5 & 3 & 4 & 3 & 2 \\
\hline 4 & 4 & 4 & 2 & 3 \\
\hline 5 & 3 & 3 & 1 & 4 \\
\hline
\end{tabular}

$\mathrm{R}=$\begin{tabular}{|c|c|c|c|c|}
\hline 1 & 0,75 & 1 & 1 & 0,5 \\
\hline 0,8 & 1 & 1 & 0,6 & 0,75 \\
\hline 1 & 0,75 & 0,75 & 0,3 & 1 \\
\hline
\end{tabular}

Selanjutnya adalah menghitung nilai preferensi untuk setiap alternatif (Vi) dengan rumus. Hasil dari perhitungan nilai preferensi sebagai berikut:

$$
\begin{aligned}
& \mathrm{V} 1=(1)(3)+(0,75)(2)+(1)(2)+(1)(2)+(0,5)(3)=10 \\
& \mathrm{~V} 2=(0,8)(3)+(1)(2)+(1)(2)+(0,6)(2)+(0,75)(3)=9,85 \\
& \mathrm{~V} 3=(1)(3)+(0,75)(2)+(0,75)(2)+(0,3)(2)+(1)(3)=9,6
\end{aligned}
$$

Berdasarkan perhitungan nilai preferensi dapat diketahui bahwa V1 memiliki nilai terbesar dibandingkan dengan V2 dan V3 dengan nilai 9,7. Dengan demikian alternatif A1 adalah alternatif yang terpilih sebagai alternatif terbaik. Alternatif A1 merupakan mahasiswa yang sebelumnya pernah menjadi asisten dosen mata kuliah dasar pemrograman dan memiliki nilai referensi (C4) terbesar dibandingkan 2 mahasiswa yang lain (A2 dan A3).

4. Implementasi Sistem

Sistem pendukung keputusan pemilihan peminatan yang telah dibuat menggunakan aplikasi My SQL untuk pembuatan databasenya. Terdapat 2 buah tabel dimana tabel pertama merupakan tabel calon asisten dosen yang berisi NPM, Nama, dan 5 nilai kriteria pendukung keputusan yaitu IPK, tes pemrograman kemampuan mengajar, nilai referensi, dan kerja sama. Sedangkan tabel kedua berisi data NPM, C1, C2. C3, C4, C5, dan total hasil nilai perhitungan. Sistem dirancang menggunakan aplikasi Netbeans IDE 8.2 dan memiliki 2 buah JFrame Form utama yaitu:

a. Frame Input Data Calon Asisten Dosen

Frame Input Data Calon Asisten Dosen digunakan untuk menyimpan, merubah, dan menghapus data mahasiswa. Data yang dimasukkan adalah NPM, Nama, Nilai IPK, Nilai Tes Pemrograman, Kemampuan Mengajar, Nilai Referensi, dan Kerja Sama. Frame Input Data Mahasiswa dapat dilihat pada Gambar 1. 


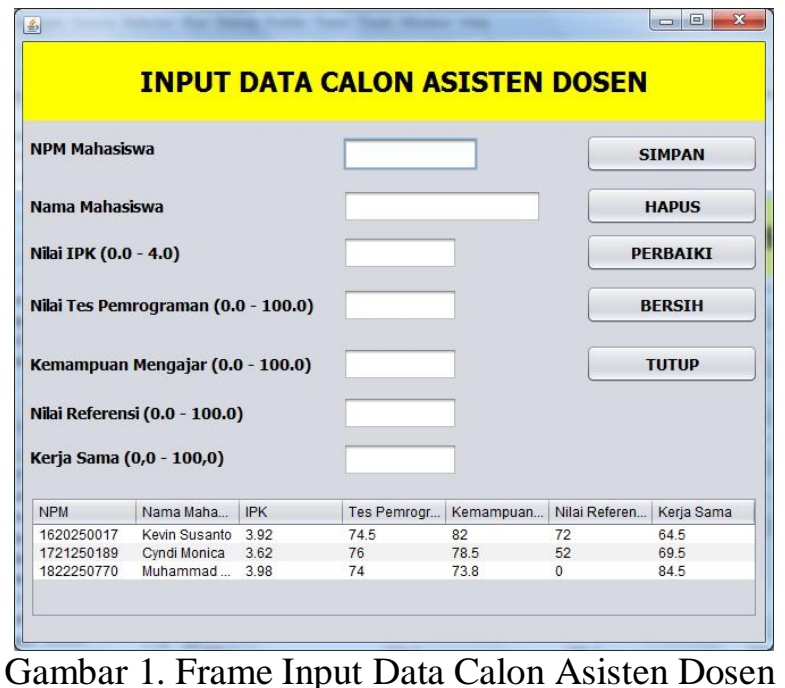

\section{b. Frame Olah SPK}

Pada saat Frame Olah SPK dijalankan maka akan menampilkan tabel calon asisten dosen yang berisi data mahasiwa dan nilai kriteria yang telah diinput sebelumnya. Tabel matriks $\mathrm{X}$ juga akan tampil berdasarkan nilai kriteria (C1-C5) dan bobot nilai (Tabel 3 dan Tabel 4). Tabel bobot akan tampil berdasarkan yang diinput (Tabel 5). Saat pengguna menekan tombol proses, maka akan tampil perhitungan normalisasi dan hasil total dari normalisasi untuk setiap alternatif/calon asisten dosen. Tabel hasil nilai akan mengurutkan npm, nama, dan total nilai yang didapat oleh setiap calon asisten dosen dari total nilai terbesar sampai yang terkecil. Jadi, baris paling atas atau baris pertama pada tabel hasil nilai merupakan alternatif yang terbaik atau calon asisten terbaik yang dapat menjadi rujukan. Tombol simpan digunakan untuk menyimpan data NPM, C1, C2, C3, C4, C5 (dari tabel Matriks X) dan total nilai (dari tabel hasil nilai) ke database. Frame Olah SPK dapat dilihat pada Gambar 2

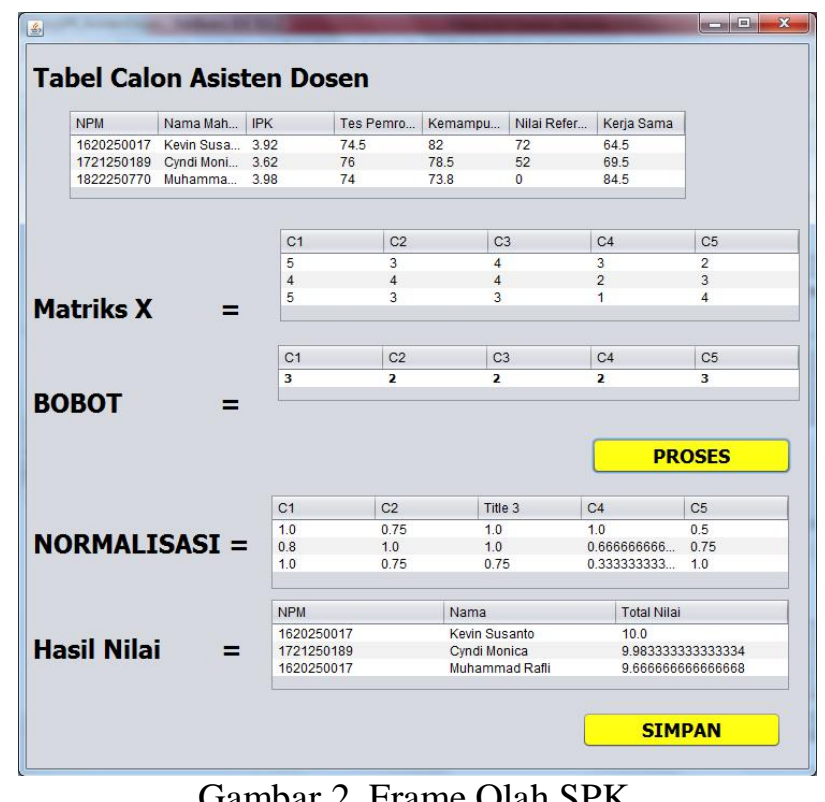




\section{KESIMPULAN}

Sistem pendukung keputusan pemilihan asisten dosen ini telah dapat membantu bagian akademik mengambil keputusan calon asisten mahasiswa mana yang mereka pilih hasil nilai dari 5 kriteria yang diinput. Selain itu, sistem ini juga dapat membantu kepala program studi dan dosen pengampu mata kuliah untuk mengetahui mahasiswa-mahasiswa yang pernah menjadi asisten dosen sebelumnya berdasarkan nilai referensinya.

\section{SARAN}

Sistem pendukung keputusan pemilihan peminatan program studi Teknik Informatika ini dapat dikembangkan lebih lanjut dengan menambahkan kriteria selain nilai mata kuliah seperti kriteria ipk, minat, dll. Sistem juga dapat dikembangkan dengan menambahkan soal soal yang harus dijawab oleh mahasiswasehingga hasil dari jawaban mahasiswa terhadap soalsoal tersebut dapat menentukan peminatan yang cocok. Selain itu dapat pula dikembangkan dengan metode lain seperti AHP atau metode yang lain sehingga dapat diketahui metode mana yang paling cocok untuk pemilihan peminatan program studi Teknik Informatika.

\section{UCAPAN TERIMA KASIH}

Penulis mengucapkan terima kasih kepada kepala program studi Teknik Informatika STMIK XYZ beserta para dosen dan mahasiswa yang telah membantu dalam pengambilan data pada penelitian ini.

\section{DAFTAR PUSTAKA}

[1] S. H. Kusumadewi, 2006, "Fuzzy Multi-Attribute Decision Making (Fuzzy MADM)," Graha Ilmu, Yogyakarta.

[2] D. Nofriansyah, 2014, “Konsep Data Mining Vs Sistem Pendukung Keputusan - Dicky Nofriansyah, M.Kom. - Google Buku,” Deepublish.

[3] T. Tinaliah and T. Elizabeth, 2019, "Sistem Pendukung Keputusan Pemilihan Peminatan Program Studi Teknik Informatika Menggunakan Metode SAW,” JATISI (Jurnal Tek. Inform. dan Sist. Informasi)

[4] H. Bartolomius and S. Palupi, 2015, "Sistem Pendukung Keputusan Penerimaan Asisten Laboratorium Komputer Menggunakan Metode Simple Additive Weighting (Studi Kasus pada Laboratorium Komputer Stmik Widya Cipta Dharma Samarinda),” Pros. Semin. Ilm. Nas. Teknol. Komput. (SENATKOM 2015), Vol. 1, No. Senatkom, pp. 90-95.

[5] R. Rosmiati, 2017, "Sistem Pendukung Keputusan Pemilihan Asisten Laboratorium Menggunakan Metode Simple Additive Weighting (SAW), " J. SAINTEKOM.

[6] L. Ivanjelita, E. Utami, and E. Luthfi, 2015, "Sistem Pendukung Keputusan Seleksi Penerimaan Calon Asisten Praktikum,” Data Manaj. dan Teknol. Inf. 
[7] I. G. S. Diputra, I. M. D. Susila, and I. N. Y. A. Wijaya, 2015, "Penentuan Minat Asisten Dosen Dengan Metode Saw Berbasis Web (Studi Kasus: Stmik Stikom Bali)," JOSIKOM J. Online Sist. Komput.

[8] Tati Mardiana, 2018, "Sistem Pendukung Keputusan Penerimaan Asisten Laboratorium Komputer Menggunakan Metode Ahp-Topsis,” J. Ilmu Pengetah. Dan Teknol. Komput.

[9] $R$. Somya and R. Wardoyo, 2019, "Perancangan SPK Seleksi Asisten Dosen Menggunakan Kombinasi Metode Profile Matching dan TOPSIS Berbasis Web Service," Khazanah Inform. J. Ilmu Komput. dan Inform.

[10] J. L. Whitten, L. D. Bentley, and K. C. Dittman, 2007, "Metode Desain dan Analisis Sistem," Andi, Yogyakarta 